Publisher: Faculty of Agronomy Čačak $\overline{=}$ www.afc.kg.ac.rs

\title{
Technological characteristics of fermented milk product manufactured by milk-dates mixtures
}

\author{
Ahmed Hariri ${ }^{*}$, Naouel Ouis², Kada Ibri ${ }^{1}$, Djilali Bouhadi ${ }^{1}$, Zouaoui Benatouche ${ }^{1}$ \\ 1,* Bioconversion Laboratory, Microbiology Engineering and Health Safety, University Mustapha STAMBOULI of Mascara \\ (UN 2901), BP. 763, Sidi Said, Mascara, 29000, Algeria. \\ 2 Laboratory of Physical Chemistry of Macromolecules and Biological Interfaces, University Mustapha STAMBOULI of \\ Mascara (UN 2901), BP. 763, Sidi Said, Mascara, 29000, Algeria.
}

*Corresponding author: ahmed.hariri@univ-mascara.dz

Received 23 March 2020; Accepted 13 July 2020

\begin{abstract}
A B S T R A C T
The objective of this study was the elaboration and characterization of milk-dates mixtures and utilization of this new food system for the production of steamed yoghurt. Dates at 9,20 and $30 \%$ were mixed with milk at $30{ }^{\circ} \mathrm{C}$ and $45^{\circ} \mathrm{C}$ for 2.5 hours. The addition of dates to milk increased the levels of density, viscosity, dry matter, proteins, pectin, ash and mineral salts. A certain stability of the quantity of lactose and a slight decrease in total fat were observed. The percentage of sugars increased gradually and stabilized at a value of $6 \%$ compared with the control $4.5 \%$. All samples of milk were of satisfactory hygienic quality. Milkdates mixtures were appreciated by panelists for their best color taste and flavor. The mixture prepared at $30{ }^{\circ} \mathrm{C}$ remained stable after 19 hours while the mixture at $45^{\circ} \mathrm{C}$ became a coagulum after 7 hours. The emulsifying power increased gradually with the concentration of the dates used and the foaming power of the control milk was the highest compared with the mixtures, i.e. it was $26.8 \%$ at the beginning, and then decreased to $16.6 \%$ after $45 \mathrm{~min}$. Yoghurts prepared with milk-dates mixtures were marked by good biochemical, microbiological and sensory characteristics. The study found that the new milk-dates system is very rich in nutritional elements and able to produce steamed yoghurts of good quality and high acceptability to consumers.
\end{abstract}

Keywords: date, milk, mixture, quality, yoghurt.

\section{И 3 В О Д}

Циљ овог рада је био разрада и карактеризација смеша млеко-урме и употреба овог новог система за производњу јогурта на пари. 9, 20 и 30 \% урми су мешани са млеком на $30{ }^{\circ} \mathrm{C}$ и $45{ }^{\circ} \mathrm{C}$ током 2,5 сата. Додавање урми млеку повећало је ниво густине, вискозности, суве материје, протеина, пектина, пепела и минералних соли. Примећена је одређена стабилност количине лактозе и благи пад укупне масти. Проценат шећера се постепено повећавао и стабилизовао на вредности од $6 \%$ у поређењу са контролном 4,5\%. Сви узорци млека су били задовољавајућег хигијенског квалитета. Мешавину млеко-урме су анкетирани потрошачи најбоље оценили због њеног најбољег изгледа и укуса. Смеша припремљена на 30 ${ }^{\circ} \mathrm{C}$ остала је стабилна после 19 сати, док је смеша на $45^{\circ} \mathrm{C}$ постала коагулум после 7 сати. Моћ емулговања постепено се повећавала са концентрацијом употребљених урми, а пенушавост контролног млека била је највећа у поређењу са смешама, тј. На почетку је износила 26,8\%, а затим се смањила на 16,6\% након 45 минута. Јогурти припремљени са млечним мешавинама обележени су добрим биохемијским, микробиолошким и сензорним карактеристикама. Студија је открила да је нови систем млечних-урме веома богат нутритивним елементима и способан је да произведе париране јогурте доброг квалитета и високе прихватљивости за потрошаче.

Кључне речи: урме, млеко, мешавине, квалитет, јогурт.

\section{Introduction}

The fruit of the date palm (Phoenix dactylifera L.) is one of the most abundant fruits in the world. The date palm belonging to the Arecaceae family is an important crop for many countries (Al-Khalifah et al., 2013). It has been cultivated across the Middle East and North Africa for over 5000 years (Chandrasekaran and Bahkali, 2013). The date fruit contains a wide range of nutritional functional substances. It is rich in digestible sugars like glucose, fructose and sucrose (70\%), dietary fibers, proteins, pectin, lipids, mineral salts, and vitamins (Al-Farsi et al., 2006). Most of the carbohydrates in this product are in the form of glucose and fructose, which are easily absorbed by the human body. The varietal structure of Algerian palm dates provides varieties of high quality and excellent commercial value destined for export and local consumption (Deglet-Nour). Other varieties known as common dates (Hmira, H'loua) are of low market value, less appreciated, and of negligible commercial interest and limited economic importance (Ahmadnia and Sahari, 2008). The large quantities of the produced dates do not meet the minimum quality attributes for direct use. Therefore, low and medium quality dates that are not directly consumed by humans have been used as raw materials of the fermentation industry or animal feed for many years and are considered low-price. The non-use of this by-product for human food constitutes 
a real economic loss. Recently, innovative date byproducts have been developed aiming at producing value added products of higher nutritional value. However, the production of sweeteners of high nutritional quality from date by-products for granular sucrose substitution in food formulations is a prime target. Dates at different forms (date syrup, date concentrate, date powder, and date liquid sugar) are ideal substitutes for added sugar in foods due to their economic value and richness in sugars and bioactive molecules. The scientific evidence states that higher consumption of added sugar (refined white sugar) increases the risk of overweight and obesity and also other risk factors for cardiovascular diseases (Johnson and Yon, 2010). Dates have been used in several food preparations in order to replace added sugar. Dates were used in the preparation of yoghurt in the form of syrup (Gad et al., 2010), fiber (Hashim et al., 2009) and powder (Hariri et al., 2018). However, the qualities, especially texture and color of reformulated products, were affected. All these date by-products are in a liquid state having different physical properties compared with sucrose and their application in food production faces major difficulties. These are due to the highly viscous liquid like state of date by-products causing operational and technological challenges for their packaging, transport, handling, piping and mixing with other ingredients. Moreover, the inclusion of highly viscous date by-products into yoghurt is likely to change the activity of the starter culture and final product quality. Until now, milk-date mixtures have not been used in food formulations. This by-product, due to its homogeneity, can be used as an ingredient of choice for many food formulations such as yoghurt, and can enhance the quality of reformulated products compared with the utilization of other date derivates. This study aimed to investigate the elaboration and characterization of the milk-dates mixture and its ability to produce fermented milk (yoghurt).

\section{Material and Methods}

\section{Chemical substances}

All solvents and chemicals were purchased from Sigma Aldrich (Munich, Germany), unless other specified.

\section{Plant material and optimization of milk-dates mixture}

The fruits of the common date variety H'loua at the tamr stage of maturity were harvested in September 2017 from the region of Adrar (South of Algeria). The choice of this variety was based on its availability, low cost and its important nutritive value, especially the content of reducing sugars. For the preparation of milkdates mixtures, date fruits were washed, pitted, cut into small particles and crushed. Preliminary tests were performed to optimize the diffusion of the date components to the milk. Various parameters governing this diffusion were optimized (diffusion duration, temperature and filtration). The OFAT (one factor at a time) method was used to optimize these parameters. This diffusion can be verified by the evaluation of the amounts of dry matter and total sugar. In order to optimize the duration of diffusion, the milk-dates mixture was prepared at $30{ }^{\circ} \mathrm{C}$ at a percentage of $20 \%$ and the dry matter and sugar contents were determined at different times. The duration of diffusion was 2.5 hours. To optimize temperature, the percentage of dates used was fixed at $20 \%$ for 2.5 hours and the temperature was varied between 30 and $45^{\circ} \mathrm{C}$, the temperature chosen was $45^{\circ} \mathrm{C}$. To verify the effect of filtration, milk-dates mixtures were prepared at different percentages for 2.5 hours at $45{ }^{\circ} \mathrm{C}$ and the amounts of sugar and dry matter before and after filtration were determined. Finally, date powder was mixed with milk at various percentages $(9,20$ and $30 \%$ ), homogenized with an Ultra-Turrax T25 mixer (IKA-Werke GmbH, Germany) at $30^{\circ} \mathrm{C}$ and $45^{\circ} \mathrm{C}$ for 2.5 hours and then filtered. Physico-biochemical, rheological, microbiological and sensory characteristics of the milk-dates mixtures were determined.

\section{Physico-biochemical characterization}

The proximate composition of the samples was analyzed chemically according to the official methods of analysis described by the Association of Official Analytical Chemists (AOAC 2007). The viscosity was measured by using a drop bile viscometer (HAAKE) and the density was evaluated at $25{ }^{\circ} \mathrm{C}$ by weighing the sample contained in a $25 \mathrm{~mL}$ pycnometer using a fourdigit Sartorius-GE412 balance, Germany (JagannadhaRao et al., 2009). The $\mathrm{pH}$ was measured using a digital pH meter (Mettler Toledo. MP220) and titratable acidity (TA) was evaluated by manual titration of 10 $\mathrm{mL}$ with standardized $0.1 \quad \mathrm{~N} \quad \mathrm{NaOH}$ using phenolphthalein as indicator. The volume of $\mathrm{NaOH}$ required to neutralize the sample was recorded and used to calculate the content of titratable acids. The dry matter level was calculated after evaporation of the water present in the sample placed in an oven $105^{\circ} \mathrm{C}$ for 24 hours (SPAG, Massy, France) until constant mass was obtained. Total sugar was evaluated colorimetrically at $480 \mathrm{~nm}$ by the Dubois method (Dubois et al., 1956). Standards were prepared with glucose solutions at different concentrations. For quantification of the pectin content, $10 \mathrm{~g}$ of the sample (noted M) was mixed under stirring with $10 \mathrm{~mL}$ of $10 \%$ $\mathrm{NaOH}$. After standing for $5 \mathrm{~min}, 4$ to $8 \mathrm{~mL}$ of $5 \mathrm{~N} \mathrm{HCl}$ (37\% of purity) were added and the mixture was heated for $5 \mathrm{~min}$, and then filtrated. The capsule was placed in an oven $105{ }^{\circ} \mathrm{C}$ until constant mass was obtained and noted (P1). After drying, the sample was introduced in a muffle furnace (Nabertherm, Germany) at $700{ }^{\circ} \mathrm{C}$; we noted a further weight $\mathrm{P} 2$ (AOAC, 2007). The percentage of pectin was calculated by the following formula: Pectin $\%=\left(\mathrm{P}_{1}-\mathrm{P}_{2} / \mathrm{M}\right) * 100$. Total nitrogen and protein content were evaluated by the Kjeldahl method (AOAC, 2007). The protein content was determined using a factor of 6.25. The formaldehyde titration assay was used to determine the total protein content of dairy products (Ceirwyn, 1999). The lactose and total fat contents were evaluated by the Bertrand and Gerber methods, respectively (Wehr and Frank, 2004; O'Connor, 1995). The ash content was determined according to the AOAC official method 972.15 by incineration of 5 grams of sample in a muffle furnace (Nabertherm, Germany) at $600{ }^{\circ} \mathrm{C}$ for 3 hours (AOAC, 2007). The levels of mineral elements were determined using an atomic absorption emission spectrophotometer according to the method advocated by Hamon et al. (1990). 


\section{Rheological analysis}

For evaluation of the stability and ability to coagulate, milk-dates mixtures were prepared at $30{ }^{\circ} \mathrm{C}$ and $45{ }^{\circ} \mathrm{C}$ and titratable acidity (TA) was evaluated at different time intervals. The time required for the mixture to begin to coagulate was noted as well. To evaluate the emulsifying power (Ahmedna et al., 1999), $1 \mathrm{~mL}$ of the sample was added to $10 \mathrm{~mL}$ of the lipid and centrifuged at $3000 \mathrm{rpm}$ for 20 minutes (Sigma laborzentrifugen D-37620 Osterode am Harz, Germany). The lipid retention capacity was calculated from the following formula:

\section{Lipid retention capacity $=\frac{\mathrm{P} 1-\mathrm{P} 2}{\mathrm{P} 2} * 100$}

P1: Weight of the pellet in gram, P2: Weight of the test sample. The activity and stability of the foam were determined by the method described by Lin et al. (1974). An aliquot of $10 \mathrm{~mL}$ of the sample was homogenized with an Ultra-Turrax T25 mixer (IKAWerke $\mathrm{GmbH}$, Germany) and immediately transferred into a $50 \mathrm{~mL}$ graduated cylinder. After stirring for 5 minutes, foam volume was measured. Foaming capacity was expressed as a percentage increase in volume. Foam stability was expressed as foam volume remaining after 15,30 and 45 minutes.

\section{Microbiological evaluation}

The microbiological quality of the samples was evaluated by enumeration of total plate count TPC in the TGEA (Trioptone Extract Glucose Agar) after incubation at $30{ }^{\circ} \mathrm{C}$ for 72 hours. All colonies were counted on those plates containing 30 to 300 colonies and multiplied by the dilution factor. Arithmetic average was counted as total plate count per gram (Anon 2000). Total coliforms were counted in desoxycholate lactose agar for 24 to 48 hours at $37^{\circ} \mathrm{C}$ (Tribst et al. 2009). Mean Salmonella count was obtained in Salmonella agar and the plates were incubated for 24 to 48 hours at $37^{\circ} \mathrm{C}$, after enrichment in Selenite-F Broth (SFB) medium for 24 to 48 hours at $37{ }^{\circ}$ C. Staphylococcus aureus counts were determined on Giolitti Cantoni and Chapman agar after 24-48 hours at $37^{\circ} \mathrm{C}$. The yeasts and molds were counted on Potato Dextrose Agar supplemented with oxytetracycline after incubation for 5 days at $25{ }^{\circ} \mathrm{C}$. All colonies were counted on the plates containing less than 50 colonies and multiplied by the dilution factor.

\section{Sensory evaluation (Metin, 2006)}

All samples were evaluated for sensory characteristics (taste, color, texture and flavor) by 20 panelists (students and technicians from University of Mascara); using a point scale (5: good, 3: acceptable, 1: bad). Each sample was evaluated using Quantitative Descriptive Profile Analysis (QDA) according to El-Dash (1978).

Potential use of milk-dates mixture for preparation of steamed yoghurt
A commercial frozen yoghurt starter culture containing Lactobacillus delbrueckii subsp. bulgaricus and Streptococcus thermophilus obtained from the GIPLait unit of Tizi (Mascara, in West of Algeria) was reactivated by inoculation in sterilized milk. One liter of partially skimmed milk was sterilized at $100{ }^{\circ} \mathrm{C}$ for 5 minutes and then the temperature was decreased to 45 ${ }^{\circ} \mathrm{C}$. The starter culture was then mixed at a $1: 1$ ratio and incubation was carried out at $45{ }^{\circ} \mathrm{C}$ until maturation (titratable acidity of 75 to $80^{\circ} \mathrm{D}$ ). The fermentation was stopped by cooling to $4{ }^{\circ} \mathrm{C}$. For the manufacture of the control yoghurt (CY), $54 \mathrm{~g}$ of milk powder at $0 \%$ of fat content and 80 grams of crystallized sucrose were added to one liter of partially skimmed pasteurized milk. The mix was heated to $95{ }^{\circ} \mathrm{C}$ for $2 \mathrm{~min}$, homogenized and then rapidly cooled to $45{ }^{\circ} \mathrm{C}$. The starter culture was added to the mix at $2 \%$ and then agitated. Incubation was carried out at $45^{\circ} \mathrm{C}$ for 2 to 3 hours (until the acidity of 70 to $80^{\circ} \mathrm{D}$ ) and stopped by cooling to $4{ }^{\circ} \mathrm{C}$. Four steamed yoghurts were manufactured: Control (CY), MY9 (utilization of milkdates mixture at 9\%), MY20 (20\%) and MY30 (30\%). All yoghurts were stocked at $4{ }^{\circ} \mathrm{C}$ and then analyzed after $1,7,15$ and 21 days of storage for proximate composition $\left(\mathrm{pH}\right.$ at $25{ }^{\circ} \mathrm{C}$, titratable acidity $\mathrm{TA}$, dry matter, total proteins, total sugar, fat and ash content). Sensory characteristics were evaluated to determine the acceptability of the yoghurts after 21 days of storage.

\section{Statistical analysis}

All analyses were done in triplicate. The data were statistically evaluated by analysis of variance ANOVA at the level of significance $p \leq 0.05$ using Microsoft Excel 2010 and SPSS Statistics software 8.1 .

\section{Results and discussion}

\section{Optimization of milk-dates mixture parameters}

This preliminary test was conducted to optimize the diffusion of date components to the milk. For optimization of diffusion time, the results showed that the percentage of dry matter changed with increasing diffusion time from $10.6 \pm 0.3$ to $12.8 \pm 0.3 \%$ after 1 hour, to $16.5 \pm 0.1$ after 2.5 hours and to $19 \pm 0.1 \%$ after 3 hours of action. Total sugar evolved from $3 \pm 0.1$ to $4.3 \pm 0.1 \%$ after 1 hour, and then stabilized at a value of $4.5 \pm 0.2 \%$ after 2.5 and 3 hours. We opted for a milk-date mixing duration of 2.5 hours. For optimization of the temperature, the percentage of dry matter increased from $11 \pm 0.2 \%$ to $14.2 \pm 0.3 \%$ at 30 ${ }^{\circ} \mathrm{C}$ and from $11 \pm 0.2 \%$ to $19 \pm 0.1 \%$ at $45{ }^{\circ} \mathrm{C}$. The temperature chosen was $45{ }^{\circ} \mathrm{C}$. Results showed that in filtered mixtures, the amount of dry matter was $18.4 \pm$ $0.2,26.8 \pm 0.1$ and $28.4 \pm 0.1 \%$ for mixtures at 9,20 and $30 \%$, respectively, compared with unfiltered mixtures $14 \pm 0.3,16.4 \pm 0.3$ and $20.8 \pm 0.2$. For total sugar, in filtered mixtures, the level of sugar was $4.4 \pm 0.03,4.4 \pm$ 0.02 and $4.6 \pm 0.02$ at 9,20 and $30 \%$, respectively, compared with unfiltered mixtures: $4.5 \pm 0.01,4.5 \pm$ 0.02 and $4.5 \pm 0.03 \%$. Filtration considerably reduced the percentage of dry matter. After filtration, the color of the mixture became darker depending on the concentration used compared with the unfiltered mixture. It seems that the filtration operation removes 
the fibers that have the ability to absorb pigments and sugar.

\section{Proximate composition}

The $\mathrm{pH}$ values of the date flesh and powder dates were $5.9 \pm 0.03$ and $5.5 \pm 0.02$, respectively. The obtained results concord with the work of Abekhti et al. (2013). During preparation of the mixtures, certain organic acids diffused and gave a slightly acidic character to the milk, which explains the decrease in the $\mathrm{pH}$ from $6.94 \pm 0.04$ to $6.79 \pm 0.04$ and the increase in the TA from $16 \pm 0.3$ to $24 \pm 0.3{ }^{\circ} \mathrm{D}$ (Table 1). This variation of TA was lower and it had no effect on the final quality and acceptability of the milk-dates mixture to consumers. The density and viscosity of the milkdates mixture increased gradually with the percentage of the dates used. The increase in these parameters was due to the contribution of soluble matter to the composition of the aqueous phase and of insoluble fibers to the increase in total solids, and affected the three dimensional conformation of the hydrated biopolymers. Our results are in agreement with the findings of Salem et al. (2017). Smith et al. (1984) reported that an increase of the changes in arrangement of water molecules around the sugar molecules were able to bring about changes in water absorption and increase the viscosity. The moisture content of the date flesh was $13.4 \%$, and the dry matter content $86.6 \%$. This value is in agreement with the results $10.57 \%$ obtained by Abekhti et al. (2013). Date powders had a total dry matter content of $95.96 \%$; this value is not consistent with the result $89 \%$ obtained by El-Sharnouby et al. (2012). The addition of dates to the milk increased the total dry matter of all milk-dates preparations. The migration of date substances to the milk explains the considerable increase in the level of dry matter from $12.6 \pm 0.2 \%$ for milk to $22.8 \pm 0.2 \%$ for mixture at $30 \%$ of dates. The carbohydrate contents of date flesh and date powder $(84.1 \pm 0.3$ and $85.7 \pm 0.1$, respectively) are higher than the results $65 \%$ cited by Benahmed et al. (2013). Carbohydrates, including soluble sugar and dietary fiber, are the predominant components of date palm (44-88\%), followed by moisture, with only a small amount of fat $(0.2-0.5 \%)$, proteins $(2.3-5.6 \%)$, dietary fiber (6.4-11.5) and ash (Al-Shahib and Marshall, 2003).

\section{Table 1}

Proximate composition of dates, date powder and milk-dates mixtures.

\begin{tabular}{|c|c|c|c|c|c|c|}
\hline \multirow[t]{2}{*}{ Parameters } & \multicolumn{2}{|c|}{ Dates } & \multicolumn{4}{|c|}{ Milk-dates mixtures } \\
\hline & Flesh & Powder & Control & $9 \%$ & $20 \%$ & $30 \%$ \\
\hline $\mathrm{pH}$ at $25^{\circ} \mathrm{C}$ & $5.9 \pm 0.03$ & $5.5 \pm 0.02$ & $6.94 \pm 0.04$ & $6.91 \pm 0.03$ & $6.89 \pm 0.04$ & $6.79 \pm 0.04$ \\
\hline $\mathrm{TA}^{\circ} \mathrm{D}$ & $2.38 \pm 0.2$ & $4.2 \pm 0.1$ & $16 \pm 0.3$ & $18 \pm 0.2$ & $24 \pm 0.3$ & $24 \pm 0.3$ \\
\hline Density $\mathrm{Kg} / \mathrm{m}^{3}$ & / & / & $1028 \pm 1$ & $1058 \pm 2$ & $1066 \pm 2$ & $1078 \pm 3$ \\
\hline Viscosity Pas. s & / & / & $1.5 \pm 0.01$ & $1.6 \pm 0.01$ & $1.7 \pm 0.01$ & $2 \pm 0.01$ \\
\hline Dry matter (\%) & $86.6 \pm 0.2$ & $95.96 \pm 0.3$ & $12.6 \pm 0.2$ & $16 \pm 0.3$ & $18.4 \pm 0.2$ & $22.8 \pm 0.2$ \\
\hline Total sugar \% & $84.1 \pm 0.3$ & $85.7 \pm 0.1$ & $4.5 \pm 0.02$ & $6 \pm 0.02$ & $6 \pm 0.01$ & $6 \pm 0.03$ \\
\hline Proteins \% & $0.48 \pm 0.02$ & $0.27 \pm 0.1$ & $3.03 \pm 0.04$ & $3.72 \pm 0.02$ & $4.06 \pm 0.02$ & $4.06 \pm 0.03$ \\
\hline Lactose g/L & / & / & $45.5 \pm 0.3$ & $45.6 \pm 0.2$ & $45.8 \pm 0.3$ & $45.2 \pm 0.3$ \\
\hline Pectin (cold) \% & 3.6 & 5.2 & 0 & $1.18 \pm 0.01$ & $6.38 \pm 0.01$ & $6.98 \pm 0.01$ \\
\hline Pectin (hot) \% & / & / & 0 & $1.04 \pm 0.02$ & $2.36 \pm 0.01$ & $2.99 \pm 0.2$ \\
\hline Fat g/L & $2.1 \pm 0.2$ & $3.2 \pm 0.3$ & $13 \pm 0.2$ & $12.7 \pm 0.1$ & $12.3 \pm 0.1$ & $11.7 \pm 0.1$ \\
\hline Ash \% & $1.9 \pm 0.03$ & $2.2 \pm 0.01$ & $0.4 \pm 0.03$ & $0.73 \pm 0.02$ & $0.96 \pm 0.02$ & $1.13 \pm 0.01$ \\
\hline \multicolumn{7}{|c|}{ Mineral salts mg/100 mL } \\
\hline K & 590 & 630 & $200 \pm 3$ & $320 \pm 2$ & $377 \pm 2$ & $454 \pm 1$ \\
\hline $\mathrm{Na}$ & / & / & $28.5 \pm 1$ & $21.4 \pm 1$ & $21.3 \pm 1$ & $21.4 \pm 1$ \\
\hline $\mathrm{Ca}$ & 570 & 625 & $286 \pm 2$ & $326 \pm 1$ & $352 \pm 2$ & $354 \pm 3$ \\
\hline $\mathrm{Fe}$ & 18 & 22 & $0.17 \pm 0.01$ & $0.19 \pm 0.01$ & $0.19 \pm 0.01$ & $0.19 \pm 0.01$ \\
\hline
\end{tabular}

Values represent Mean $\pm \mathrm{Sd} ; \mathrm{n}=3$, confidence level $p \leq 0.05$, /: non-determined

Whatever the concentration of the dates used, the quantity of sugar that diffuses was constant, about
$1.5 \%$, which was added to the initial $4.5 \%$ of the milk. This result on the composition of milk-dates mixtures 
corroborates the report of Belewu et al. (2014) and ElSharnouby et al. (2014). Date palm is rich in dietary fiber; soluble dietary fibers contribute to the formation of a viscous gel and increase the viscosity of the milkdates mixture. This gel decreases the rate of diffusion of sugar to the milk, which explains the constant content of sugar in the mixture. The majority of the proteins present in the dates diffuse towards the milk thus contributing to the protein enrichment of the mixture. Pectin substances are polysaccharides attached to carbohydrates and constitute plant cell walls and the date pulp. Pectin was found to accumulate in dates until it reaches the Rutab stage with minimal activity of pectin esterase enzyme (Mustafa et al., 1986). The amount of these substances increased with increasing percentage of dates used. The diffusion of these substances at $30{ }^{\circ} \mathrm{C}$ was more intense, causing partial gelling of the mixture compared to the diffusion at 45 ${ }^{\circ} \mathrm{C}$; this gelling only occurs after several hours of rest. The amount of lactose in the milk remains constant

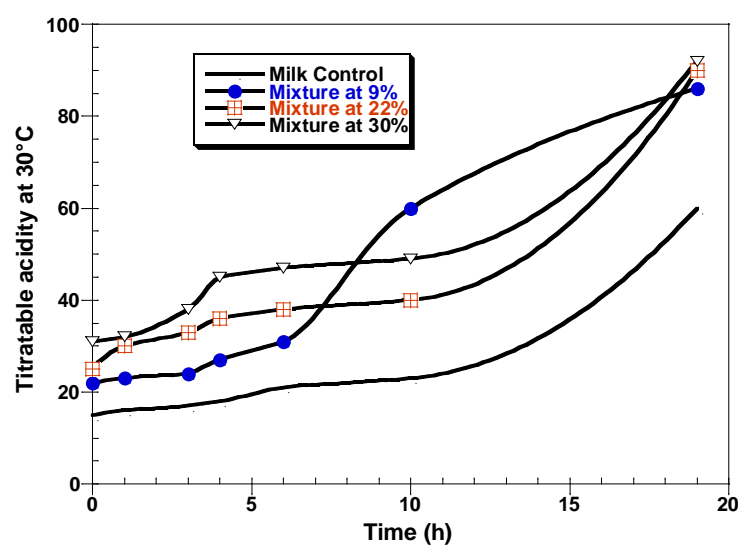

since dates do not contain lactose. The fat content of the mixture decreases slightly with the increase in the amount of dates used. These substances can be absorbed by date fibers and retained on the filter; this can explain the increase in the density of the mixture. Dates are a good source of certain minerals (potassium and calcium), which explains the considerable ash content in the mixtures. The addition of dates to the milk improves the composition of the mixture in terms of ash and mineral salts.

\section{Rheological characteristics}

The stability and ability of the mixture to coagulate were determined by measuring TA at $30{ }^{\circ} \mathrm{C}$ and $45^{\circ} \mathrm{C}$. Dates are rich in mono sugars and organic acids. The TA of the mixtures increased with an increase in the percentage of the dates used (Figure 1).

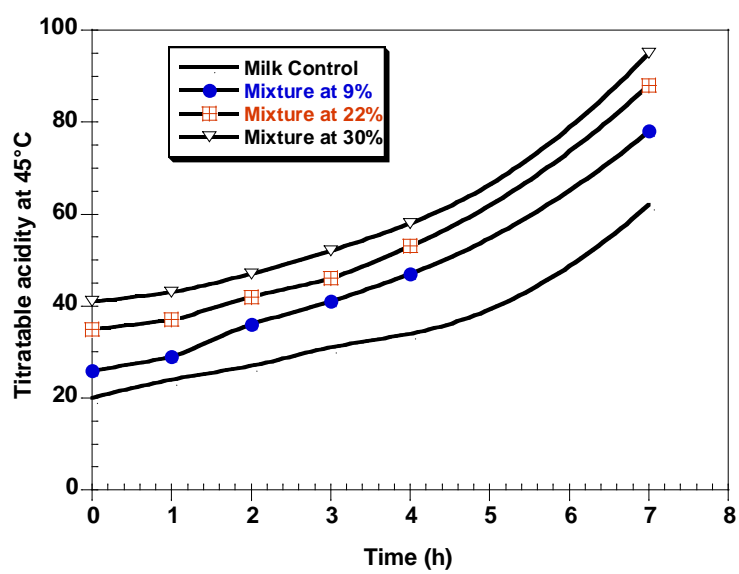

Figure 1. Evolution of the titratable acidity of milk and milk-dates mixture prepared at $30{ }^{\circ} \mathrm{C}$ and $45^{\circ} \mathrm{C}$.

For the control milk at $30^{\circ} \mathrm{C}$, the TA evolved from $15 \pm 0.2$ to $23 \pm 0.1^{\circ} \mathrm{D}$ after 10 hours and reached $60 \pm$ $0.2{ }^{\circ} \mathrm{D}$ after 19 hours. At $45{ }^{\circ} \mathrm{C}$, the TA evolved exponentially and reached $62 \pm 0.1^{\circ} \mathrm{D}$ after 7 hours. This acidification is the sign of coagulation of the samples. It seems that the mixture prepared at $30^{\circ} \mathrm{C}$ remained stable for 19 hours while the mixture at $45^{\circ} \mathrm{C}$ became a coagulum after 7 hours. Several substances diffused from the dates to the milk, which can be attributed to various technological and functional properties of the mixtures such as emulsifying power and foaming activity. The interaction between proteins and lipids is common in many food systems, and thus the ability of proteins to form stable emulsions is important. The emulsifying power of the milk control and the mixtures at 9,20 and $30 \%$ was $60,70,80$ and $85 \%$, respectively. The emulsifying power increased gradually with increasing concentration of the dates used. Thus, considering these emulsifying properties, dates could be used as ingredients in emulsion-based food formulations such as dressing and mayonnaise, where functional properties are especially important. Some food proteins are capable of forming good foams, and their capacity to form and stabilize foams depends on the type of protein, degree of denaturation, $\mathrm{pH}$, temperature and whipping methods (Lqari et al., 2005). The lifetime of the foam of the milk-dates mixture at $20 \%$ lasted for $60 \mathrm{~min}$ and the destruction of this foam was achieved after $80 \mathrm{~min}$. The volume of the foam disappeared rapidly in the control milk and other mixtures at $9 \%$ and $30 \%$ (Figure 2). The foaming power of the control milk was highest compared with the mixtures, i.e. it was $26.8 \%$ at the beginning, and then decreased to $16.6 \%$ after $45 \mathrm{~min}$. By contrast, in the presence of dates, the foaming power was very weak. These results indicate that the milk added to dates changes characteristics and becomes a totally different system. The dates bring substances that interact with milk caseins and fat, thus modifying their foaming effect. This characteristic can be applied in the formulation of foods in which the presence of foam is undesirable without the use of antifoam agents. 


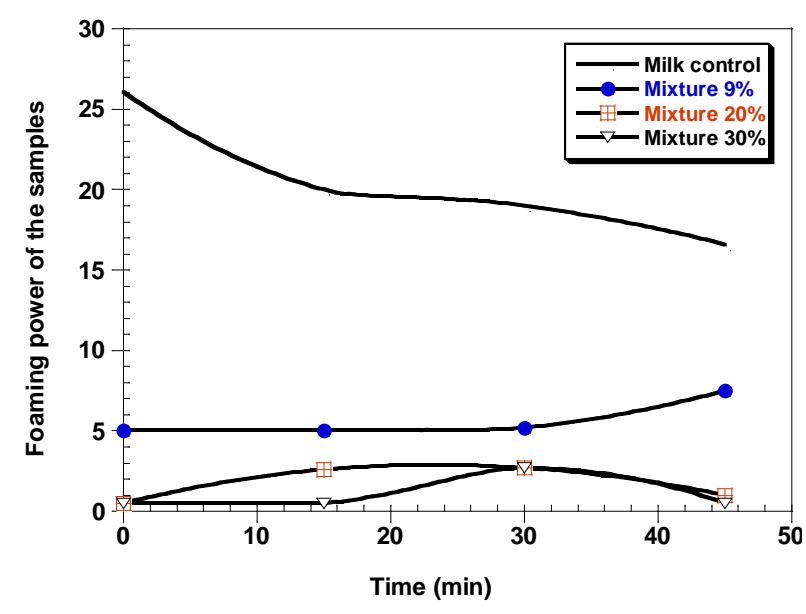

(a). Foaming power

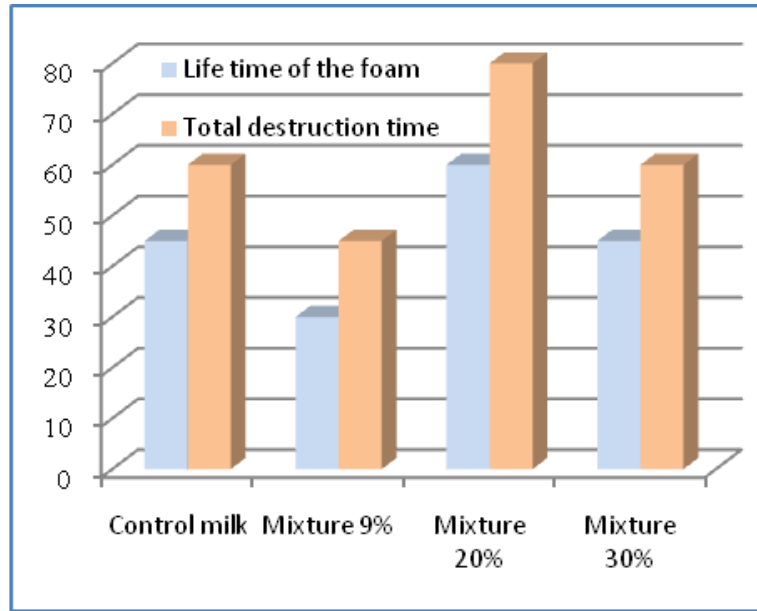

(b) Life time and destruction time of the foam

Figure 2. Foaming activity of the milk control and milk-dates mixtures

\section{Microbiological evaluation}

Actually, milk and dairy products are a great medium for the growth of many spoilage and pathogenic microorganisms. TPC in the milk control was $3^{*} 10^{4} \mathrm{CUF} / \mathrm{mL}$. This value is in line with the findings of Joffin and Joffin (2003). For milk-dates mixture samples, TPC ranged from $3^{*} 10^{4}$ to $4^{*} 10^{4}$ $\mathrm{CUF} / \mathrm{mL}$. This is logical because the dates used were not packed and not sterilized and that cause bacterial contamination. The result of microbiological evaluation indicated complete absence of total coliforms, Staphylococcus aureus, and Salmonella in all milk samples. Yeasts and molds were found in the milkdates mixtures and ranged from 24 for $9 \%, 70$ for $20 \%$ and 110 yeasts $/ \mathrm{mL}$ for $30 \%$ because these microorganisms could withstand the acidity of the mixture. The milk control was marked by a total absence of these microorganisms. All mixtures were of satisfactory hygienic quality and did not involve any risk of toxi-infection to consumers.

\section{Sensory evaluation}

The sensory evaluation of the samples was conducted to determine the acceptability of the product to consumers. The samples were evaluated for color, flavor and taste characteristics. Milk flavor was influenced by the presence of fat and other flavoring compounds present in the milk or imparted by dates. The richness of dates in flavoring components such as fructose improved the taste of the milk-dates mixture. The acceptability of flavor and color of the mixtures increased gradually with the percentage of the dates used. According to the results presented in Table 2, the mixtures at 20 and $30 \%$ of dates were best appreciated by panelists and had the best color and flavor, followed by the mixture at $9 \%$ and the milk control. According to the panel members, the taste of the mixture at $20 \%$ was best appreciated $80 \%$, followed by mixture $9 \%$, mixture $30 \%$ and the control. Our results are in agreement with the work of Belewu et al. (2014).

Table 2

Sensory evaluation of the milk control and milk-dates mixture

\begin{tabular}{lcccc}
\hline Sensory characteristics & Samples & Good & Acceptable & Bad \\
\hline \multirow{3}{*}{ Color } & Milk control & 40 & 40 & 20 \\
& Mixtures 9\% & 40 & 35 & 25 \\
& Mixtures 20\% & 70 & 20 & 10 \\
& Mixtures 30\% & 65 & 25 & 10 \\
\hline \multirow{3}{*}{ Flavor } & Milk control & 30 & 50 & 20 \\
& Mixtures 9\% & 35 & 40 & 25 \\
& Mixtures 20\% & 65 & 25 & 10 \\
Taste & Mixtures 30\% & 65 & 30 & 10 \\
& Milk control & 45 & 45 & 20 \\
& Mixtures 9\% & 60 & 15 & 30 \\
\hline
\end{tabular}


Formulation of steamed yoghurt using milkdates mixtures

\section{Proximate composition}

This study was carried out to determine the possibility of this new system (milk-dates mixture) to produce a fermented product (yoghurt). During incubation period at $45{ }^{\circ} \mathrm{C}$, the TA of the milk control and milk with dates at $30 \%$ evolved, respectively, from 28 and $35^{\circ} \mathrm{D}$ to $70{ }^{\circ} \mathrm{D}$ after 4.5 hours. For yoghurts manufactured with milk-dates mixtures at 9 and $20 \%$, the TA increased from 35 to $80{ }^{\circ} \mathrm{D}$ after 4.5 hours of incubation. This can be explained by the richness of dates in sugars, especially glucose, which are transformed by lactic acid bacteria and produce more lactic acid. During the storage period at $4{ }^{\circ} \mathrm{C}$, the TA of the $\mathrm{CY}$ gradually increased from $78^{\circ} \mathrm{D}$ to $100{ }^{\circ} \mathrm{D}$ after 21 days, while the preparation of the yoghurts with milk-dates caused a slight increase in acidity from 85 at the first day of storage to the values ranging between 103 and $108^{\circ} \mathrm{D}$ (Table 3 ). This acidity explains the low values of $\mathrm{pH}$ obtained for milk-dates mixture yoghurts compared with the control. The TA of CY increased during the incubation period due to the utilization of residual sugars by viable lactic starters and production of lactic acid (Parmjit and Shinde, 2012). Proteolytic enzymes secreted by microorganisms degrade yoghurt proteins into free amino acids and contribute to an increase in acidity (Widyastuti and Febrisiantosa, 2014). Our results confirm the findings of several authors (Bachir Raho and Benattouche, 2013; Kucukoner and Tarakci, 2003), who found that the TA values increased with the storage time. According to Hess et al. (1997), the $\mathrm{pH}$ of the yoghurt should be in the range of 4 to 5 . Our results are in agreement with the findings of Bachir Raho and Benattouche (2013), and Singh et al. (2011), who reported a decrease in the $\mathrm{pH}$ of yoghurt during the storage period. The dry matter was represented mainly by sugars, proteins, mineral salts, fats and vitamins of the yoghurt. The decrease in the level of these parameters was proportional to the duration of storage due to the use of these nutrients by ferments and microorganisms. Yoghurts manufactured with milk-dates mixtures preserved their nutritional elements after 21 days of storage.

Table 3

Results of the physico-biochemical characterization of steamed yoghurts

\begin{tabular}{|c|c|c|c|c|c|}
\hline \multirow{2}{*}{ Parameters } & \multirow{2}{*}{$\begin{array}{c}\text { Steamed } \\
\text { yoghur } \\
\text { ts }\end{array}$} & \multicolumn{4}{|c|}{ Days of storage } \\
\hline & & 1 & 7 & 15 & 21 \\
\hline \multirow[t]{4}{*}{$\mathrm{pH}$ at $25^{\circ} \mathrm{C}$} & $\mathrm{CY}$ & $4.7 \pm 0.1$ & $4.5 \pm 0.2$ & $4.3 \pm 0.2$ & $4 \pm 0.2$ \\
\hline & MY9 & $4.5 \pm 0.2$ & $4.2 \pm 0.1$ & $4 \pm 0.2$ & $3.8 \pm 0.1$ \\
\hline & MY20 & $4.5 \pm 0.1$ & $4.3 \pm 0.1$ & $4.1 \pm 0.3$ & $3.7 \pm 0.2$ \\
\hline & MY30 & $4.3 \pm 0.2$ & $4.1 \pm 0.1$ & $3.8 \pm 0.1$ & $3.5 \pm 0.1$ \\
\hline \multirow[t]{4}{*}{ Titratable acidity $\left({ }^{\circ} \mathrm{D}\right)$} & $\mathrm{CY}$ & $78 \pm 0.2$ & $85 \pm 0.1$ & $92 \pm 0.3$ & $100 \pm 0.2$ \\
\hline & MY9 & $85 \pm 0.3$ & $91 \pm 0.1$ & $98 \pm 0.1$ & $108 \pm 0.2$ \\
\hline & MY20 & $84 \pm 0.2$ & $91 \pm 0.1$ & $98 \pm 0.3$ & $107 \pm 0.1$ \\
\hline & MY30 & $80 \pm 0.1$ & $88 \pm 0.2$ & $96 \pm 0.2$ & $103 \pm 0.1$ \\
\hline \multirow[t]{4}{*}{ Dry Mater (\%) } & $\mathrm{CY}$ & $17 \pm 0.2$ & $15 \pm 0.3$ & $12 \pm 0.2$ & $7 \pm 0.2$ \\
\hline & MY9 & $22 \pm 0.3$ & $19 \pm 0.1$ & $16 \pm 0.3$ & $12 \pm 0.2$ \\
\hline & MY20 & $25 \pm 0.3$ & $22 \pm 0.3$ & $18 \pm 0.1$ & $15 \pm 0.1$ \\
\hline & MY30 & $27 \pm 0.3$ & $24 \pm 0.3$ & $19 \pm 0.1$ & $17 \pm 0.1$ \\
\hline \multirow[t]{4}{*}{ Total Proteins (\%) } & $\mathrm{CY}$ & $4.4 \pm 0.1$ & $4.3 \pm 0.3$ & $4.1 \pm 0.2$ & $3.6 \pm 0.3$ \\
\hline & MY9 & $4.7 \pm 0.2$ & $4.6 \pm 0.2$ & $4.5 \pm 0.1$ & $4.1 \pm 0.1$ \\
\hline & MY20 & $4.9 \pm 0.2$ & $4.9 \pm 0.1$ & $4.7 \pm 0.1$ & $4.4 \pm 0.2$ \\
\hline & MY30 & $4.9 \pm 0.1$ & $4.8 \pm 0.3$ & $4.7 \pm 0.3$ & $4.3 \pm 0.2$ \\
\hline \multirow[t]{4}{*}{ Total sugars (\%) } & $\mathrm{CY}$ & $13 \pm 0.2$ & $11 \pm 0.3$ & $9 \pm 0.3$ & $6.5 \pm 0.2$ \\
\hline & MY9 & $15 \pm 0.1$ & $13 \pm 0.3$ & $11 \pm 0.1$ & $09 \pm 0.2$ \\
\hline & MY20 & $15 \pm 0.4$ & $14 \pm 0.3$ & $10 \pm 0.4$ & $10 \pm 0.3$ \\
\hline & MY30 & $16 \pm 0.3$ & $14 \pm 0.2$ & $12 \pm 0.2$ & $11 \pm 0.1$ \\
\hline \multirow[t]{4}{*}{ Total Fat (g/L) } & $\mathrm{CY}$ & $15 \pm 0.2$ & $14.8 \pm 0.1$ & $14.3 \pm 0.1$ & $14.2 \pm 0.1$ \\
\hline & MY9 & $14.8 \pm 0.2$ & $14.6 \pm 0.1$ & $14.4 \pm 0.2$ & $14.1 \pm 0.1$ \\
\hline & MY20 & $14.9 \pm 0.2$ & $14.7 \pm 0.1$ & $14.2 \pm 0.2$ & $13.8 \pm 0.1$ \\
\hline & MY30 & $14.7 \pm 0.2$ & $14.3 \pm 0.1$ & $14.1 \pm 0.2$ & $13.7 \pm 0.1$ \\
\hline \multirow[t]{4}{*}{ Ash (\%) } & $\mathrm{CY}$ & $1.3 \pm 0.1$ & $0.8 \pm 0.2$ & $0.77 \pm 0.2$ & $0.62 \pm 0.1$ \\
\hline & MY9 & $1.7 \pm 0.2$ & $1.3 \pm 0.1$ & $1.3 \pm 0.2$ & $1.2 \pm 0.1$ \\
\hline & MY20 & $1.9 \pm 0.3$ & $1.6 \pm 0.2$ & $1.5 \pm 0.1$ & $1.5 \pm 0.2$ \\
\hline & MY30 & $2.1 \pm 0.2$ & $1.8 \pm 0.1$ & $1.8 \pm 0.2$ & $1.7 \pm 0.1$ \\
\hline
\end{tabular}

Values represent Mean $\pm \mathrm{Sd} ; \mathrm{n}=3$, confidence level $p \leq 0.05$ 


\section{Microbiological evaluation}

Results of the microbiological analysis indicated a complete absence of total coliforms, Staphylococcus aureus, fecal streptococci and Salmonella in all types of yoghurt and throughout the storage period. This absence can be explained by the satisfaction of hygienic requirements, the effectiveness of heat treatments and the acidifying activity of the lactic ferments which inhibit the proliferation of these germs. As regards yeasts and molds, these microorganisms appeared in the first week of storage ( 5 yeasts $/ \mathrm{mL}$ ), and then this number increased to 7 yeasts $/ \mathrm{mL}$ during the last week of storage for yoghurts manufactured with milk dates. Results of microbiological evaluation indicated good quality of the yoghurts. Our results of all yoghurts are in line with the findings of Olmedo et al. (2013).

\section{Sensory evaluation}

Yoghurt is a fermented milk product with a refreshing flavor, a slight sour taste and a smooth viscous gel (Bodyfelt et al., 1988). These sensory properties offer quality control criteria, and, therefore, yoghurt should be evaluated for flavor, color, taste, and texture. Yoghurt flavor is influenced by the presence of lactic acid and other flavoring compounds produced by the culture starter during the fermentation process. The texture of yoghurt is affected by the rate of acid production during the fermentation process, as well as by the fat content and presence of stabilizing agents such as gelatin, milk solids, and sugar. Heating the mix denatures whey proteins, increases the water-holding capacity of milk protein, and reduces syneresis in yoghurt (Hekmat and McMahon, 1992). The taste of yoghurt comes from the aromas produced by lactic ferments during storage, mainly diacetyl and butyric acid. According to the results, the MY20 and MY30 received the best scores from the members of the panel for their flavor, taste and color. The panelists gave the highest score for texture to the CY and MY9 (Table 4).

Table 4

Sensory evaluation of steamed yoghurts

\begin{tabular}{lcccc}
\hline Sensory characteristics & Steamed yoghurts & Good & Acceptable & Bad \\
\hline Flavor & CY & 45 & 35 & 20 \\
& MY9 & 55 & 30 & 15 \\
& MY20 & 75 & 25 & $/$ \\
& MY30 & 80 & 15 & 05 \\
\hline Taste & CY & 50 & 35 & 15 \\
& MY9 & 60 & 25 & 15 \\
& MY20 & 80 & 15 & 05 \\
\hline Texture & MY30 & 65 & 20 & 15 \\
& CY & 75 & 15 & 10 \\
& MY9 & 70 & 15 & 15 \\
& MY20 & 45 & 20 \\
& MY30 & 40 & 35 & 30 \\
\hline Color & CY & 50 & 30 & 15 \\
& MY9 & 50 & 15 & 20 \\
& MY20 & 75 & 20 & 10 \\
\hline
\end{tabular}

\section{Conclusion}

This study showed that the combination of dates and milk as a new food system is stable, very rich in nutritional elements, of good microbiological quality and highly evaluated for its overall consumer acceptability. The date added to the milk changed characteristics and became a totally different system marked by an increase in emulsifying power and a decrease in foaming activity. The new milk-dates system was found to be able to produce steamed yoghurts of good quality and high acceptability to consumers.

\section{References}

Abekhti, A., Zarour, K., Boulal, A., Benmechernene, Z., Kihal, M. (2013). Evaluation of microbiological quality of the date fruit product "Btana" produced in Adrar South Algeria. Journal of Microbiology Research, 3(5), 163-170.
Ahmadnia, A., Sahari, MA. (2008). Using date powder in formulation of chocolate toffee. Iranian Journal of Food Science and Technology, 5(3), 1-8.

Ahmedna, M., Prinyawiwatkul, W., Rao, RM. (1999). Solubilized wheat protein isolate: Functional properties and potential food applications. Journal of Agricultural and Food Chemistry, 47, 1340-1345.

Al-Farsi, M., Alasalvar, C., Al-Abid, M., Al-Shoaly, K., Al-Amry, M., Al-Rawahy, F. (2006). Compositional and functional characteristics of dates, syrups, and their by-products. Food Chemistry, 104, 943-947.

Al-Khalifah, NS., Askari, E., Shanavaskhan, AE. (2013). Date palm tissue culture and genetical identification of cultivars grown in Saudi Arabia. National Center for Agriculture Technologies, King Abdulaziz City for Science and Technology (KACST), Saudi Arabia.

Al-Shahib, W., Marshall, RJ. (2003). The fruit of the date palm: its possible use as the best food for the future. International Journal of Food Sciences and Nutrition, 54, 247-259.

Anon. (2000). Approved methods for analysis. 10th Ed. The American association of cereal chemists (AACC). St. Paul, MN. 
AOAC. (2007). Official methods of Analysis of AOAC international. Gaithersburg. Maryland.

Bachir Raho, G., Benattouche, Z. (2013). Evaluation of the quality of steamed yogurt treated by Lavandula and Chamaemelum species essential oils. Journal of Medicinal Plants Research, 7(42), 3121-3126.

Belewu, MA., Muhammed-Lawal, A., Abdulsalam, K., Belewu, KY., Belewu, N.O. (2014). Date-coconut drink: physicochemical and sensory qualities. Daffodil international university journal of science and technology, 9(2), 1-6.

Benahmed, D.A., Saidi, N., Mekssoud, A., Benamara, S. (2013) Pharmacological and biological proprieties of a mixture of date powders (mech-degla and spirulina). A Multidisciplinary Journal of Global Macro Trends, 2(1), 310-320.

Bodyfelt, FW., Tobias, J., Trout, GM. (1988), Sensory evaluation of dairy products. New York NY7 Van Rostrand Teinhold, 22-31.

Ceirwyn, S.J. (1999): Analytical chemistry of foods. Edition Chapman and Hall, New York, 90.

Chandrasekaran, M., Bahkali, A.H. (2013): Valorization of date palm (Phoenix dactylifera) fruit processing byproducts and wastes using bioprocess technology-Review. Saudi Journal of Biological Sciences, 20(2), 105-120.

Dubois, M., Gilles, K.A., Hamilton, J.K., Rebers, P.A., Smith, F. (1956). Colorimetric method for determination of sugars and related substances. Analytical Chemistry, 38(3), 350356.

El-Dash, A. (1978). Standardized mixing a fermentation procedure for experimental baking test. Cereal Chemistry, $55,336$.

El-Sharnouby, C.A., Aleid, S.M., Al-Qtaibi, M.M. (2014). Liquid sugar extraction from date palm (Phoenix dactylifera $\mathrm{L}$.) fruits. Journal of Food Processing \& Technology, 5 (12), 15 .

El-Sharnouby, G.A., Aleid, S.M., Al-Otaibi, M.M. (2012). Nutritional quality of biscuit supplemented with wheat bran and date palm fruits (Phoenix dactylifera L.). Food and Nutrition Sciences, 3, 322-328.

Gad, A.S., Kholif, A.M., Sayed, A.F. (2010). Evaluation of the nutritional value of functional yogurt resulting from combination of date palm syrup and skim milk. American Journal of Food Technology, 1-10.

Hamon, M., Pellerin, F., Guenet, M., Maauzier, G. (1990). Speed analytical chemistry: organic methods and spectral analyses. Masson, Paris, 232-233.

Hariri, A., Ouis, N., Bouhadi, D., Benatouche, Z. (2018). Characterization of the quality of the steamed yoghurts enriched by date flesh and date powder variety H'loua. Banats Journal of Biotechnology, IX(17): 31-39.

Hashim, I.B., Khalil, A.H., Afif, H.S. (2009). Quality characteristics and consumer acceptance of yoghurt fortified with date fiber. Journal of Dairy Sciences, 92(11), 5403-5407.

Hekmat, S., McMahon, D.J. (1992): Survival of Lactobacillus acidophilus and Bifidobacterium bifidum in ice cream for use as a probiotic food. Journal of Dairy Sciences, 75, 1415-20.

Hess, S.J., Roberts, R.F., Ziegler, G.R. (1997): Rheological properties of nonfat yogurt stabilized using Lactobacillus delbrueckii ssp. bulgaricus producing exopolysaccharide or using commercial stabilizer systems. Journal of Dairy Sciences, 80, 252-263
Jagannadha-Rao, P.V., Das, M., Das, S.K. (2009). Changes in physical and thermo-physical properties of sugarcane, palmyra-palm and date-palm juices at different concentration of sugar. Journal of Dairy Sciences, 90(4), 559-566.

Joffin, C., Joffin, J.N. (2003). Microbiologie alimentaire. 5. Ed. CEDP, Aquitaine.

Johnson, R.K., Yon, B.A. (2010). Weighing in on added sugars health. Journal of the American Dietetic Association, 110, 1296-1299.

Kucukoner, E., Tarakci, Z. (2003). Influence of different fruit additives on some properties of stirred yogurt during storage. Tarim Bilimleri Dergisis, 13(2), 97-101.

Lin, M.J., Humbert, E.S., Sosulski, F.W. (1974). Certain functional properties of sunflower meal products. Journal of Food Science, 39, 368-370.

Lqari, H., Pedroche, J., Girón-Calle, J., Vioque, J., Millán, F. (2005). Production of lupines angustifolius protein hydrolysates with improved functional properties. Grasasy Aceites, 56(2), 135-140.

Metin, M. (2006). Analysis Methods of Milk and Dairy products (sensory, physical and chemical analysis). Ege University Publications, Bornova.

Mustafa, A.B., Harper, D.B., Johnston, D.E. (1986). Biochemical changes during ripening of Sudanese date varieties. Journal of the Science of Food and Agriculture, 37(1), 4353.

O'Connor, C.B. (1995): Rural dairy technology. ILRI Training manual. 1. International livestock research institute. Addis Ababa, Ethiopia.

Olmedo, R.H., Nepote, V., Grosso, N.R. (2013): Preservation of sensory and chemical properties in flavoured cheese prepared with cream cheese base using oregano and rosemary essential oils. Food Science and Technology, 53, 409-417.

Parmjit, S.P., Shinde, C. (2012). Effect of storage on syneresis, $\mathrm{pH}$, Lactobacillus acidophilus count, Bifidobacterium bifidum count of Aloe vera fortified probiotic yoghurt. Current Research in Dairy Sciences, 4, 17-23.

Salem, S.A., Fardous, M., Meead, G., El-Rashody, H. (2017): Effect of camel milk fortified with dates in ice cream manufacture on viscosity, overrun, and rheological properties during storage period. Food and Nutrition Sciences, 8, 551-564.

Singh, G., Singh, K.I.P., Singh, P. (2011). Effect of volatile oil and oleoresin of anise on the shelf life of yogurt. Journal of Food Process Preservation, 35, 778-783.

Smith, D.E., Bakshi, A.S., Lomauro, C.J. (1984): Changes in function of sweetener system and whey substitution. Milchwissenschaft, 39, 455.

Tribst, A.A., Sant'Ana, S., De Massaguer, P.R. (2009): Microbiological quality and safety of fruit juices-past, present and future perspectives. Critical Reviews in Microbiology, 35(4), 310-339.

Wehr, H.M., Frank, J.F. (2004): Standard methods for the examination of dairy products. 17th Ed. 324-404, American Public Health Association, Baltimore, USA: 363527.

Widyastuti, Y., Febrisiantosa, RA. (2014). The role of lactic acid bacteria in milk fermentation. Food and Nutrition Sciences, 5, 435-442. 